\title{
PERLINDUNGAN HUKUM BAGI KONSUMEN DALAM PERJANJIAN BAKU JUAL BELI PERUMAHAN DENGAN PIHAK PENGEMBANG DI BALI
}

Oleh

A.A Gde Agung Brahmanta*, Prof. Dr. Ibrahim, R. SH., MH,**, Dr. I Made Sarjana, SH., MH.***

Magister Kenotariatan Universitas Udayana

E-mail : agungbrahmanta@yahoo.com

\section{ABSTRACT}

\section{Legal Protection for Consumers in the Standard Housing Sale and Purchase Agreement with Developers in Bali}

The rapid population growth makes the need for homes also increase. There are many emerging developer companies that offer home that could be obtained on credit. Real Estate Developer parties usually make an agreement with consumers in the form of standard contract, so that the consumers here have no bargaining power but to accept what is specified by the developer. This causes consumer to have less legal protection as opposed to what is contained in the provisions of Law No. 8 of 1999 concerning Consumer Protection. The problem faced is how the position of the buyers as consumers in the purchase of standard agreement of housing, as well as how the legal protection that can be provided to the consumer in the standard housing sale and purchase agreement with developers in Bali.

This research is empirical legal research whose objects of study are the terms and provisions regarding the enforcement or implementation of normative law (codification, law or contract) is in action / in abstracto on any legal events that occur in the community (in concreto). The data source used in this study is primary data and secondary data.

The results of this study indicate that the Status of the buyer as a consumer in the standard housing sale and purchase agreement has a weaker position compared to the business party (developer), this is because the purchase agreement offered by the business is made in the standard contract format so that consumers do not have bargaining power over what is contained in the clauses of the home purchase agreement. Legal protection that can be provided to the consumer in standard housing sale and purchase agreement with developers in Bali, namely if in the field there is a breach of the provisions set out in the Consumer Protection Act, a developer as the party carrying out the business can legally be sued by consumers as parties who feel aggrieved, then other measures are that a developer must also adjust the standard clause in the purchase and sale agreement that it offers is still at odds with this Law.

Keywords: protection, consumer, standard agreement, developer

\section{B A B I}

\section{PENDAHULUAN}

\subsection{Latar Belakang}

Salah satu faktor utama yang menjadi kelemahan konsumen adalah tingkat kesadaran akan haknya memang masih sangat rendah, hal ini terutama disebabkan oleh kurangnya kesadaran dari pihak konsumen itu sendiri dan rendahnya pendidikan konsumen yang ada ${ }^{1}$. Mengenai hal ini Undang-undang Nomor 8 Tahun 1999 tentang Perlindungan Konsumen, memberikan pengertian tentang perlindungan konsumen secara cukup luas, perlindungan konsumen di definisikan sebagai segala upaya yang menjamin adanya kepastian hukum untuk memberikan perlindungan kepada konsumen. Namun dalam

${ }^{1}$ Shofie, 2000, Perlindungan Konsumen dan Instrumen-Instrumen Hukumnya, Citra Aditya Bakti, Bandung, h. 74. 
kenyataannya yang terjadi bahwa

perlindungan hukum bagi pihak

konsumen dalam perjanjian baku jual

beli perumahan dengan pihak pengembang cenderung tidak memberikan perlindungan hukum yang cukup bagi pihak konsumen. Dalam hal konsumen menolak perjanjian tersebut, berarti jual beli pun tidak dapat dilaksanakan karena tidak terjadi kesepakatan. Sebagai contoh yang diangkat dalam penelitian tesis ini yaitu mengenai perjanjian baku jual beli perumahan yang ditawarkan oleh perusahaan pengembang perumahan di Bali. Dalam perjanjian baku yang ditawarkan oleh pihak beberapa Pengembang terdapat beberapa klausula yang cenderung merugikan pihak konsumen selaku pembeli. Tentunya hal ini merupakan suatu kesenjangan bila dikaitkan dengan Pasal 18 UU Perlindungan Konsumen

\subsection{Rumusan Masalah}

1. Bagaimanakah kedudukan pihak pembeli sebagai konsumen dalam perjanjian baku jual beli perumahan?

2. Bagaimanakah perlindungan hukum yang dapat diberikan kepada konsumen dalam perjanjian baku jual beli perumahan dengan pihak pengembang di Bali?

\subsection{Ruang Lingkup Masalah}

Pada permasalahan pertama dibahas tentang kedudukan pihak pembeli sebagai konsumen dalam perjanjian baku jual beli perumahan.Pada permasalahan kedua, dibahas tentang perlindungan hukum yang dapat diberikan pada pihak konsumen dalam perjanjian baku jual beli perumahan dengan pihak pengembang di Bali.

\subsection{Tujuan Penelitian}

\subsubsection{Tujuan Umum}

Untuk dapat melatih mahasiswa dalam upaya menyatakan pikiran ilmiah dan mengembangkan ilmu pengetahuan di bidang Hukum dan khususnya pada bidang Hukum Kenotariatan.Yang kelak dalam kehidupan bermasyarakat dapat berguna.

\subsubsection{Tujuan Khusus}

Untuk mengetahui kedudukan pihak pembeli sebagai konsumen dalam perjanjian baku jual beli perumahan. Untuk mengetahui perlindungan hukum bagi konsumen dalam perjanjian baku jual beli perumahan dengan pihak pengembang di Bali

\subsection{Manfaat Penelitian}

\subsubsection{Manfaat Teoritis}

Untuk menambah wawasan dan ilmu pengetahuan khususnya terhadap hukum perjanjian dan perlindungan konsumen.

\subsubsection{Manfaat Praktis}

Untuk mengetahui bentuk perjanjian yang dapat memberikan perlindungan hukum dan kepastian hukum dalam kegiatan jual beli yang dilakukannya.

\subsection{Landasan Teoritis}

Adapun asas dan teori teori yang digunakan dalam penelitian ini adalah

1. Teori Perjanjian

Subekti memberikan pendapat mengenai perjanjian adalah suatu peristiwa dimana seseorang berjanji kepada orang lain untuk melaksanakan suatu hal. Dari 
peristiwa ini timbullah suatu hubungan hukum antara dua orang tersebut yang dinamakan perikatan, perjanjian itu menerbitkan suatu perikatan antara dua orang yang membuatnya. ${ }^{2}$

2. Teori Perlindungan Konsumen

a. teori kontrak:

b. The due care theory :

c. The social cost view of the manufacturer's duties

3. Teori Keadilan Aristoteles

Menurut pandangan Aristoteles tentang keadilan bisa didapatkan dalam karyanya nichomachean ethics politics, dan rethoric. Spesifik dilihat dalam buku nicomachean ethics, buku itu sepenuhnya ditujukan bagi keadilan, yang, berdasarkan filsafat hukum Aristoteles, mesti dianggap sebagai inti dari filsafat hukumnya, "karena hukum hanya bisa ditetapkan dalam kaitannya dengan keadilan ${ }^{3}$.

\subsection{Metode Penelitian}

\subsubsection{Jenis Penelitian}

Jenis penelitian yang digunakan dalam penulisan tesis ini adalah jenis penelitian hukum empiris, yaitu penelitian hukum yang objek kajiannya meliputi ketentuan dan mengenai pemberlakuan atau implementasi ketentuan hukum normatif (kodifikasi, Undang-Undang atau kontrak) secara in action/in abstracto pada setiap peristiwa hukum

${ }^{2}$ Subekti R, 2002,Hukum Perjanjian, Cet. XIII, Intermasa, Jakarta, h. 1

${ }^{3}$ Carl Joachim Friedrich, 2004, Filsafat Hukum Perspektif Historis, Nuansa dan Nusamedia, Bandung, h. 24 yang terjadi dalam masyarakat (in (oncreto $)^{4}$.

\subsubsection{Jenis Pendekatan}

Dalam penelitian ini akan dibahas menggunakan jenis pendekatan kualitatif. Pendekatan kualitatif adalah suatu cara analisis hasil penelitian yang menghasilkan data deskriptif analitis ${ }^{5}$.

\subsubsection{Lokasi Penelitian}

Mengenai lokasi yang dipilih untuk mendapatkan data primer adalah pada perusahaan pengembang perumahan yang berkantor di Denpasar dan Badung dengan menggunakan teknik purposive/jugmental sampling, yaitu "sampel yang dipilih berdasarkan pertimbangan atau penelitian subyektif dari peneliti", 6

\subsubsection{Sumber Data}

Dalam penelitian pada umumnya dibedakan antara data yang diperoleh secara langsung dari masyarakat yang dinamakan data primer (data dasar) dan diperoleh dari bahanbahan pustaka dinamakan data sekunder ${ }^{7}$.

1. Data primer

Untuk mendapat data primer dilakukan penelitian lapangan (FieldResearch).

\section{Data sekunder}

Untuk mendapatkan data sekunder dilakukan penelitian kepustakaan (Library Research). Dengan meneliti bahan hukum primer, sekunder dan Bahan hukum tersier ${ }^{8}$.

${ }^{4}$ Abdulkadir Muhamad, 2004, Hukum dan Penelitian Hukum, Citra Aditya Bakti, Bandung, hal. 134

${ }^{5}$ Fajar, Mukti dan Yulianto Achmad, 2010, Dualisme Penelitian Hukum Normatif \& Empiris, Pustaka Pelajar, Yogjakarta, hal. 192

${ }^{6}$ Burhan Ashshofa, op.cit, hal.91

${ }^{7}$ Soerjono Soekanto dan Sri Mamudji, 2001, Penelitian Hukum Normatif, PT. Raja Grafindo Persada, Jakarta, hal. 12

${ }^{8}$ Bambang Waluyo, 2002, Penelitian Hukum Dalam Praktek, Sinar Grafika, Jakarta, h. 23 


\subsubsection{Teknik Pengumpulan Data}

Adapun teknik pengumpulan data yang dipergunakan dalam penelitian ini untuk mendapatkan data primer adalah melalui wawancara.

1.7.6 Teknik pengolahan dan analisis data

Apabila keseluruhan data yang diperoleh dan sudah terkumpul baik melalui studi kepustakaan ataupun dengan wawancara, kemudian mengolah dan menganalisis secara kualitatif yaitu dengan menghubungkan antara data yang ada.

\section{B A B II}

TINJAUAN UMUM TENTANG

PERLINDUNGAN KONSUMEN, PERJANJIAN BAKU DAN

PENGEMBANG PERUMAHAN

\subsection{Tinjauan Umum Tentang Perlindungan Konsumen}

\subsubsection{Pengertian Konsumen}

Menurut ketentuan Pasal 1 angka

2 Undang-Undang Nomor 8 tahun 1999 tentang Perlindungan Konsumen (UUPK), “Konsumen adalah setiap orang pemakai barang dan/atau jasa yang tersedia dalam masyarakat, baik bagi kepentingan diri sendiri, keluarga,orang lain, maupun makhluk hidup lain dan tidak untuk diperdagangkan".

\subsubsection{Hak dan Kewajiban Konsumen}

Konsumen berhak : atas kenyamanan, keamanan, dan keselamatan dalam mengkonsumsi barang dan/atau jasa; untuk memilih barang dan/atau jasa serta mendapatkan barang dan/atau jasa tersebut sesuai dengan nilai tukar dan kondisi serta jaminan yang dijanjikan; Hak atas informasi yang benar, jelas, dan jujur mengenai kondisi dan jaminan barang dan/atau jasa; Hak untuk didengar pendapat dan keluhannya atas barang dan/atau jasa yang digunakan; Hak untuk mendapatkan advokasi, perlindungan, dan upaya penyelesaian sengketa perlindungan konsumen secara patut; Konsumen berkewajiban : membaca atau mengikuti petunjuk informasi dan prosedur pemakaian atau pemanfaatan barang dan/atau jasa, demi keamanan dan keselamatan; beritikad baik dalam melakukan transaksi pembelian barang dan/atau jasa; membayar sesuai dengan nilai tukar yang disepakati; mengikuti upaya penyelesaian hukum sengketa perlindungan konsumen secara patut.

\subsubsection{Pengertian Perlindungan} Konsumen

Menurut ketentuan yang tercantum dalam Pasal 1 angka 1 UUPK menyatakan bahwa "perlindungan konsumen adalah segala upaya yang menjamin adanya kepastian hukum untuk memberikan perlindungan kepada konsumen.

\subsubsection{Asas dan Tujuan Perlindungan} Konsumen

a. Asas perlindungan konsumen tercantum dalam Pasal 2 UUPK yaitu Asas manfaat, Asas keadilan, Asas keseimbangan, Asas keamanan dan keselamatan konsumen, Asas kepastian hukum.

b. Tujuan Perlindungan Konsumen tercantum dalam Pasal 3 UUPK yaitu : meningkatkan kesadaran, kemampuan dan kemandirian konsumen untuk melindungi diri; mengangkat harkat dan martabat 
konsumen dengan cara

menghindarkannya dari ekses negatif pemakaian barang dan/atau jasa;

\subsection{Tinjauan Umum Tentang \\ Perjanjian Baku}

\subsubsection{Pengertian Perjanjian}

Wirjono Prodjodikoro, yang menyatakan bahwa "Perjanjian adalah suatu perhubungan hukum mengenai harta benda antar dua pihak dalam mana satu pihak berjanji atau dianggap berjanji untuk melakukan sesuatu hal atau untuk tidak melakukan sesuatu hal, sedangkan pihak lain berhak menuntut pelaksanaan janji itu"9.

\subsubsection{Syarat-Syarat}

Sahnya

\section{Perjanjian}

Menurut ketentuan yang diatur dalam Pasal 1320 KUHPerdata syarat sahnya perjanjian yaitu: sepakat mereka yang mengikatkan diri, kecakapan untuk membuat suatu perikatan, suatu hal tertentu, suatu sebab yang halal.

\subsubsection{Asas-Asas Dalam Perjanjian}

Asas-asas hukum merupakan dasar yang karena sifatnya yang fundamental dan yang dikenal didalam hukum kontrak yang klasik adalah asas konsensualisme, asas kekuatan mengikat, asas kebebasan berkontrak dan asas keseimbangan.

\subsubsection{Pengertian Perjanjian Baku}

Menurut pendapat Sutan Remy Sjahdeini menyatakan bahwa perjanjian baku adalah perjanjian yang hamper seluruh klausul-klausul yang dibakukan oleh pemakainya danpihak

${ }^{9}$ R. Wiryono Prodjodikoro, 2004, Asas-asas Hukum Perjanjian, Mandar Maju, Bandung, hal. 4. lainnya pada dasarnya tidak mempunyai peluang untuk merundingkan atau meminta perubahan.

\subsubsection{Keabsahan Perjanjian Baku}

Perjanjian baku pada kenyataannya menimbulkan banyak masalah terutama dalam hal tidak adanya persesuaian kehendak dari para pihak dan seringkali menimbulkan kedudukan yang tidak berimbang antara kedua belah pihak. Pihak debitor dalam perjanjian baku dapat diupayakan perlindungannya melalui ajaran penyalahgunaan keadaan dan ajaran itikad baaik. Jadi, apabila perjanjian baku dan klausulanya berisikan penyalahgunaan keadaan diakibatkan bertentangan dengan kesusilaan dan sebab yang tidak diperbolehkan maka akibat perjanjian tersebut adalah batal demi hukum.

2.3 Tinjauan Umum Mengenai Pengembang Perumahan

\subsubsection{Pengertian Pengembang} Perumahan

Menurut ketentuan yang tercantum dalam Pasal 1 ayat 3 UUPK menyatakan bahwa Pelaku usaha adalah setiap orang perorangan atau badan usaha, baik yang berbentuk badan hukum maupun bukan badan hukum yang didirikan dan berkedudukan atau melakukan kegiatan dalam wilayah hukum negara Republik Indonesia baik sendiri maupunbersama-sama melalui perjanjian menyelenggrakan kegiatan usaha dalam berbagai bidang ekonomi.

$$
\text { Menurut ketentuan yang }
$$

tercantum dalam Pasal 5 ayat(1) Peraturan Menteri Dalam Negeri 
Nomor 5 tahun 1974,disebutkan pengertian Perusahaan Pembangunan Perumahan yang dapat pula masuk dalam pengertian developer, yaitu: Perusahaan Pembangunan Perumahan adalah suatu perusahaan yang berusaha dalam bidang pembangunan perumahan dari berbagai jenis dalam jumlah yang besar di atas suatu areal tanah yang akan merupakan suatu kesatuan lingkungan pemukiman yang dilengkapi dengan prasarana-prasarana lingkungan dan fasilitas-fasilitas sosial yang diperlukan oleh masyarakat penghuninya.

\subsubsection{Hak, Kewajiban dan Tanggung} Jawab Pengembang Perumahan

Dalam pasal 6 UUPK menentukan hak pelaku usaha adalah :

1. Hak untuk menerima pembayaran yang sesuai dengan kesepakatan mengenai kondisi dan nilai tukar barang dan/atau jasa yang diperdagangkan.

2. Hak untuk mendapatkan perlindungan hukum dari tindakan konsumen yang tidak beritikad baik.

3. Hak untuk melakukan pembelaan diri sepatutnya di dalam penyelesaiaan hukum sengketa konsumen.

4. Hak untuk rehabilitasi nama baik apabila terbukti secara hukum bahwa kerugian konsumen tidak diakibatkan oleh barang dan/atau jasa yang diperdagangkan.

5. Hak-hak yang diatur dalam ketentuan perUndang-undangan lainnya.
Pelaku Usaha / Pengembang Perumahan dalam Pasal 7 UUPK diwajibkan :

1. Beritikad baik dalam melakukan kegiatan usahanya.

2. Memberikan informasi yang benar, jelas, dan jujur mengenai kondisi dan jaminan barang dan/atau jasa serta memberi penjelasan penggunaan, perbaikan dan pemeliharaan.

3. Memperlakukan atau melayani konsumen secara benar dan jujur serta tidak diskriminatif.

4. Menjamin mutu barang dan/atau jasa yang diproduksi dan/atau jasa diperdagangkan berdasarkan ketentuan standar mutu barang dan/atau jasa yang berlaku.

5. Memberi kesempatan kepada konsumen untuk menguji dan/atau mencoba barang dan/atau jasa tertentu serta menjamin dan/atau garansi atas barang yang dibuat dan/atau jasa yang diperdagangkan.

6. Memberi kompensasi ganti rugi dan/atau penggantian atas kerugian akibat penggunaan, pemakain dan pemanfaatan barang dan/atau jasa yang diperdagangkan.

7. Memberi kompensasi, ganti rugi atas barang dan/atau jasa yang diterima atau dimanfaatkan tidak sesuai dengan perjanjian

Tanggung jawab pelaku usaha atas kerugian konsumen dalam UndangUndang Nomor 8 tahun 1999 tentang Perlindungan Konsumen, diatur khusus dalam BAB VI, mulai dari Pasal 19 sampai dengan Pasal 28, Memperhatikan substansi Pasal 19 ayat (1) Nomor 8 tahun 1999 tentang Perlindungan Konsumen, dapat diketahui bahwa tanggung jawab pelaku usaha meliputi : 
1. Tanggung jawab ganti kerugian atas kerusakan,

2. Tanggung jawab ganti kerugian atas pencemaran,

3. Tanggung jawab ganti kerugian atas kerugian konsumen ${ }^{10}$.

\section{B AB III}

KEDUDUKAN PIHAK PEMBELI

SEBAGAI KONSUMEN DALAM

PERJANJIAN BAKU JUAL BELI

PERUMAHAN

\subsection{Hak dan Kewajiban Penjual Dan} Pembeli Menurut KUHPerdata

Seorang penjual mempunyai beberapa hak yang dilindungi oleh KUHPerdata, yaitu:

\section{HAK PENJUAL}

1. Penjual berhak untuk tidak menyerahkan barang yang dijualnya, jika si pembeli belum membayar harganya, sedangkan si penjual tidak telah mengijinkan penundaan pembayaran kepadanya, hal ini sebagaimana diatur dalam Pasal 1478 KUHPerdata ${ }^{11}$.

2. Hak menyatakan batal demi hukum, apabila pembeli tidak membayar harga pembelian, maka penjual dapat menuntut pembatalan pembelian.

3. Penjual di beri kekuasaan untuk membeli kembali barang yang telah dijual diterbitkan dari suatu janji, dimana si penjual diberikan hak untuk mengambil kembali barang yang dijualnya, dengan mengembalikan harga pembelian asal, dengan disertai penggantian sebagaimana diatur dalam Pasal 1519 KUHPerdata.

${ }^{10}$ Ahmadi Miru dan Sutarman Yodo, 2004, Hukum Perlindungan Konsumen, RajaGrafindo Persada, Jakarta, h. 125

${ }^{11}$ Riduan Syahrina, 2006, Seluk Beluk dan Asas-Asas Hukum Perdata Alumni, Bandung, h. 212
4. Semua biaya menurut hukum yang telah dikeluarkan untuk menyelenggarakan pembelian serta penyerahannya, begitu pula yang diperlukan biaya yang diperlukan untuk pembetulan-pembetulan, dan biaya yang menyebabkan barangnya yang dijual bertambah harganya, sejumlah tambahannya ini, sebagaimana diatur dalam Pasal 1532 KUHPerdata.

\section{KEWAJIBAN PENJUAL}

Mengenai kewajiban dari pihak Penjual, KUHPerdata mengaturnya yaitu sebagai berikut:

1. Penjual wajib menyatakan dengan jelas, untuk apa ia mengikatkan dirinya, janji yang tidak jelas dan dapat diartikan dalam berbagai pengertian harus ditafsirkan untuk kerugiannya. (Pasal 1473 KUHPerdata).

2. Menurut ketentuan yang diatur dalam Pasal 1474 KUHPerdata dapat diketahui bahwa Penjual memiliki 2 (dua) kewajiban utama yaitu:

a. Menyerahkan hak milik atas barang yang diperjualbelikan.

b. Menanggung kenikmatan atas barang tersebut dan menanggung terhadap kerusakan-kerusakan tersembunyi ${ }^{12}$.

3. Menurut ketantuan yang tercantum dalam Pasal 1508 KUHPerdata, apabila si penjual mengetahui adanya cacat tersembunyi yang tidak ia beritahukan kepada pembeli, maka penjual wajib untuk

a. Mengembalikan uang harga pembelian

b. Mengembalikan hasil-hasil, jika ia diwajibkan menyerahkan hasil-hasil itu kepada si pemilik sejati yang melakukan penuntutan penyerahan.

c. Mengganti segala biaya kerugian dan bunganya kepada pembeli.Dalam suatu perjanjian jual beli, seorang penjual

${ }^{12}$ Subekti, 2000, Aneka Perjanjian, Alumni, Bandung, h. 17 
tidak akan diwajibkan menanggung sesuatu apapun, namun ada pembatasannya.

\section{HAK PEMBELI}

Dalam hal tidak terlaksananya
ketentuan Pasal 1495 KUHPerdata,
dan hal tersebut tidak dicantumkan
dalam perjanjian, maka si pembeli
berhak menuntut kembali dari si
penjual:

1. Pengembalian uang harga pembelian

2. Pengembalian hasil-hasil jika ia diwajibkan menyerahkan hasil-hasil itu kepada si pemilik sejati yang melakukan tuntutan penyerahan

3. Biaya yang dikeluarkan berhubung dengan gugatan si pembeli untuk ditanggung begitu pula biaya yang telah dikeluarkan oleh penggugat asal.

4. Penggantian kerugian beserta biaya perkara mengenai pembelian dan penyerahannya, sekedar itu telah dibayar oleh si pembeli.

5. Barang yang harus diserahkan kepada pembeli adalah dalam keadaan utuh seperti pada saat penjualan atau saat perjanjian diadakan dan sejak penyerahan barang, segala yang dihasilkan dari barang tersebut menjadi hak pembeli (Pasal 1481 dan Pasal 1483 KUHPerdata).

6. Pembeli berhak mendapatkan jaminan untuk dapat memiliki barang itu dengan aman dan tentram. Serta jaminan terhadap cacat yang tersembunyi dan sebagainya, yang dapat dijadikan alasan untuk pembatalan pembelian (Pasal 1491, 1504, 1506, 1509, 1510 KUHPerdata).

7. Pembeli berhak menuntut pembatalan pembelian, jika penyerahan barang tidak dapat dilaksanakan karena akibat kelalaian penjual (Pasal 1480 KUHPerdata).
8. Dalam ketentuan Pasal 1514 KUHPerdata dinyatakan bahwa "jika pada waktu membuat persetujuan tidak ditetapkan halhal itu, pembeli harus membayar di tempat dan pada waktu penyerahan.

\section{KEWAJIBAN PEMBELI}

Selain mengatur mengenai hak-hak dari pembeli, KUHPerdata juga mengatur kewajiban daripada pembeli yaitu:

1. Pasal 1513 KUHPerdata : "kewajiban utama pembeli adalah membayar harga pembelian pada waktu dan di tempat yang ditetapkan dalam persetujuan.

2. Pasal 1514 KUHPerdata : “jika pada waktu membuat persetujuan tidak ditetapkan hal-hal itu pembeli harus membayar di tempat dan pada waktu penyerahan."

3. Pasal 1515 KUHPerdata : "Pembeli walaupun tidak ada suatu perjanjian yang tegas, wajib membayar bunga dari harga pembelian, jika barang yang dijual dan diserahkan memberi hasil atau pendapatan lain."

\subsection{Kedudukan Antara Para Pihak Dalam Perjanjian Baku Jual Beli Perumahan}

Penggunaan perjanjian baku dalam kegiatan transaksi bisnis tentunya dapat meningkatkan efisiensi, sehingga penggunaan perjanjian baku ini menyebar dalam berbagai kegiatan transaksional yang terjadi. Senada dengan pendapat yang dikemukakan oleh Slawson yang menyatakan bahwa :

Standard form contracts probably account for more than ninety-nine percent of all the contracts now made. Most persons have difficulty remembering the last time they contracted other than by standard form ; except for casual oral agreements, 
they probably never have. ${ }^{13}$

Perjanjian baku pada kenyataannya menimbulkan banyak permasalahan terutama dalam hal tidak adanya persesuian kehendak dari para pihak dan seringkali menimbulkan kedudukan yang tidak berimbang antara kedua belah pihak. Untuk mrnghindari terjadinya permasalahan maka diperlukanlah posisi yang berimbang antara para pihak dalam suatu perjanjian baku.

\subsection{Perjanjian Baku Berklausula} Eksonerasi Dalam Perjanjian Baku Jual Beli Perumahan

Perjanjian dengan syarat-syarat eksonerasi disebut pula perjanjian dengan syarat-syarat untuk pembatasan berupa penghapusan ataupun pengalihan tanggung jawab. Melalui syarat-syarat semacam ini oleh salah satudari pihak dibatasi atau dibedakan dari sesuatu tanggung jawab berdasarkan hukum. Beban tanggung jawab yang diberikan oleh peraturan perundang-undangan dihapus oleh penyusun perjanjian melalui syarat-syarat eksonerasi tersebut. ${ }^{14}$
B AB IV

PERLINDUNGAN HUKUM PADA

KONSUMEN DALAM PERJANJIAN

BAKU JUAL BELI PERUMAHAN

DENGAN PIHAK PENGEMBANG

\subsection{Tanggungjawab Pihak}

Pengembang Dalam Perjanjian

Baku Jual Beli Perumahan

\subsubsection{Tanggung Jawab Pengembang}

\section{Menurut KUHPerdata}

Atas perbuatan melawan hukum sebagaimana disebutkan diatas, maka model tanggung jawab hukumnya sesuai dengan KUHPerdata adalah sebagai berikut:

1. Tanggung jawab dengan unsur kesalahan (kesengajaan dan kelalaian) sebagaimana terdapat dalam pasal 1365 KUHPerdata.

2. Tanggung jawab dengan unsur kesalahan khususnya kelalaian sebagaimana terdapat dalam pasal 1366 KUHPerdata.

3. Tanggung jawab mutlak (tanpa kesalahan) dalam artian atasannya yang akan bertanggung jawab atas kesalahan bawahannya, sebagaimana terdapat dalam pasal 1367 KUHPerdata. $^{15}$

\subsubsection{Tanggung Jawab Pengembang} Menurut UU No. 8 Tahun 1999 Tentang Perlindungan

\section{Konsumen}

Pelaku usaha dalam menawarkan barang dan atau jasa dilarang melakukan dengan cara pemaksaan atau cara lain yang dapat menimbulkan gangguan baik fisik maupun psikis terhadap konsumen, hal

${ }^{15}$ Ibid
Contract And Democratic Control Of

Lawmaking Power, Harvard Law Review, page 529

${ }^{14}$ Ahmadi Miru dan Sutarman Yodo, 2000, Hukum Perlindungan Konsumen, Raja

Grafindo Persada, Jakarta, h. 115 
ini sebagaimana diatur dalam Pasal 15

UU Perlindungan Konsumen. Atas dasar kondisi sebagaimana dipaparkan diatas, perlu upaya pemberdayaan konsumen yang dapat melindungi kepentingan konsumen secara intergratif dan komprehensif serta dapat diterapkan secara efektif di mas yarakat.

Berdasarkan ketentuan pasal diatas maka dapat diketahui bahwa pihak pelaku usaha memiliki tanggung jawab untuk memberikan ganti kerugian atas kerusakan, pencemaran dan atas kerugian yang diderita oleh konsumen, sehingga dalam hal ini adanya produk barang dan/atau jasa yang cacat bukan merupakan satusatunya dasar pertanggung jawaban pelaku usaha.

\subsection{Pelaksanaan Perjanjian Baku} Jual Beli Perumahan Di Bali

Berdasarkan hasil penelitian yang dilakuka pada tiga developer di Bali terhadap pelaksanaan perjanjian jual beli perumahan antara pihak developer dengan konsumen, maka dapat diketahui bahwa dalam perjanjian tersebut memuat mengenai kewajiban dan hak dari masing-masing pihak tersebut yang dibagi menjadi dua tahapan yaitu tahap pendahuluan dan tahap pelaksanaan yang dapat diuraikan sebagai berikut:

\section{TAHAP PENDAHULUAN}

Hasil penelitian di lapangan terhadap salah satu konsumen dari PT. Tri Duta Dewata yaitu Ibu Grace Sedana menyatakan bahwa, pada saat hendak membeli rumah di Perumahan Baliarum Jimbaran, pihak developer memberikan penjelasan mengenai spesifikasi rumah yang dipilih oleh konsumen, kemudian apabila konsumen merasa cocok, maka pihak developer meminta konsumen untuk memenuhi persyaratan administrasi yang telah ditentukan, setelah syarat itu dipenuhi maka tiga hari kemudian pihak developer kembali menghubungi konsumen untuk memberitahukan hasilnya. (wawancara dilakukan pada tanggal 2 Mei 2014) Setelah semua proses tahap awal terpenuhi maka kemudian dilanjutkan ke proses tahap pelaksanaan.

\section{TAHAP PELAKSANAAN}

Berdasarkan hasil penelitian yang dilakukan di lapangan maka dapat diketahui bahwa dalam perjanjian jual beli rumah yang dilakukan antara pihak developer dengan konsumen, didahului dengan perjanjian pengikatan jual beli (selanjutnya disebut PPJB), yang merupakan suatu perjanjian awal adanya kesepakatan jual beli rumah. PPJB inilah yang dibuat dalam bentuk perjanjian baku oleh para developer, walaupun setiap developer memiliki perbedaan isi dan redaksional, namun substansi dalam setiap PPJB ini tetaplah sama dalam setiap developer. Secara hukum pelaksanaan perjanjian pengikatan jual belirumah antara developer dengan konsumen umumnya berjalan dengan baik. Hal tersebut disebabkan bahwa pelaksanaan perjanjian pengikatan jual beli rumah lebih mengarah pada proses 
beralihnya hak kepemilikan atas tanah dan bangunan dari developer selaku penjual kepada konsumen selaku pembeli. pihak konsumen tidak mempunyai posisi tawar atas hal-hal yang harus konsumen sepakati pada perjanjian jual beli tersebut.

\section{B AB V \\ PENUTUP}

\subsection{Kesimpulan}

1. Kedudukan pihak pembeli sebagai konsumen dalam perjanjian baku jual beli perumahan memiliki posisi yang lebih lemah dibandingkan dengan pihak pelaku usaha (developer), hal ini dikarenakan perjanjian jual beli yang ditawarkan oleh pelaku usaha dibuat dalam format perjanjian baku sehingga konsumen tidak memiliki posisi tawar atas apa yang tertuang dalam klausula perjanjian jual beli rumah tersebut, kedudukan konsumen kurang mendapatkan perlindungan hukum yang kuat karena posisi tidak seimbang ini.

2. Perlindungan hukum yang dapat diberikan kepada konsumen dalam perjanjian baku jual beli perumahan dengan pihak pengembang di Bali, yaitu apabila di lapangan terjadi pelanggaran atas

ketentuan yang diatur dalam UU Perlindungan Konsumen, maka pihak developer selaku pelaku usaha dapat dituntut secara hukum oleh pihak konsumen yang merasa dirugikan, kemudian upaya lain juga pelaku usaha wajib menyesuaikan klausula baku dalam perjanjian jual beli yang ditawarkannya yang masih bertentangan dengan Undangundang ini.

\subsection{Saran}

1. Bagi pihak konsumen yang hendak membeli rumah pada sebuah developer hendaknya lebih berhati-hati dalam memilih tawaran yang dijanjikan oleh pihak developer atas rumah yang hendak dipesan, konsumen juga hendaknya lebih cermat dalam memahami isi perjanjian yang ditawarkan.

2. Bagi pihak developer dalam menyusun perjanjian jual beli dalam bentuk baku hendaknya tidak hanya mencantumkan kewajiban dan sanksi-sanksi yang dibebankan bagi calon konsumen, perjanjian haruslah disusun untuk memberikan persamaan kedudukan bagi pihak pelaku usaha dan konsumen sehingga hak para pihak dapat terlindungi.

\section{DAFTAR BACAAN}

Adjie, Habib, 2011, Merajut Pemikiran dalam Dunia Notaris dan PPAT, Citra Aditya Bakti, Bandung.

Amiruddin dan H. Zainal Asikin, 2004, Pengantar Metode Penelitian Hukum, Raja Grafindo Persada, Jakarta.

Andasasmita, Komar Andasasmita, 2001, Notaris Selayang Pandang, Cet. 2, Alumni, Bandung.

Florianus, S.P Sangsun, 2008, Tata Cara Mengurus Sertipikat Tanah, Visimedia, Jakarta.

Miru, Ahmadi, 2007, Hukum Kontrak dan Perancangan Kontrak, Raja Grafindo Persada, Jakarta.

Soedjendro, J. Kartini, 2001, Perjanjian Peralihan Hak Atas Tanah Yang Berpotensi Konflik, Kanisius, Yogyakarta. 
Sunggono, Bambang, 2010, Metodologi Penelitian Hukum, Rajawali Pers, Jakarta.

Suyanto, Bagong dan Sutinah, 2011, Metode Penelitian Social, Kencana Prenada Media Group, Jakarta.

Salim H.S, 2008, Hukum Kontrak, Sinar Grafika, Jakarta

$* * * * *$ 